\title{
BMJ Open Association between perception of bodily discomfort and individual and work organisational factors in Brazilian slaughterhouse workers: a cross-sectional study
}

\author{
Adriana Seára Tirloni, ${ }^{\oplus 1}$ Diogo Cunha dos Reis, ${ }^{\oplus 1}$ Adriano Ferreti Borgatto, ${ }^{\circledR 2}$ \\ Antônio Renato Pereira Moro 1
}

To cite: Tirloni AS, Reis DC, Borgatto AF, et al. Association between perception of bodily discomfort and individual and work organisational factors in Brazilian slaughterhouse workers: a crosssectional study. BMJ Open 2019;9:e022824. doi:10.1136/ bmjopen-2018-022824

- Prepublication history for this paper is available online. To view these files, please visit the journal online (http://dx.doi. org/10.1136/bmjopen-2018022824).

Received 7 March 2018 Revised 22 November 2018 Accepted 26 November 2018

Check for updates

(C) Author(s) (or their employer(s)) 2019. Re-use permitted under CC BY-NC. No commercial re-use. See rights and permissions. Published by BMJ.

${ }^{1}$ Applied Ergonomics Laboratory, Federal University of Santa Catarina, Florianópolis, Santa Catarina, Brazil

${ }^{2}$ Department of Informatics and Statistics, Federal University of Santa Catarina, Florianopolis, Santa Catarina, Brazil

Correspondence to Dr Adriana Seára Tirloni; adri@tirloni.com.br

\section{ABSTRACT}

Objective Brazil is the world's second largest poultry meat producer and leading exporter. Many poultry processing tasks are physically demanding and involve factors that increase the risk of developing a workrelated musculoskeletal disorder (WMSD). However, little is known about the assessment of bodily discomfort in these workers. The aim of this study was to evaluate the association between perception of bodily discomfort and individual and work organisational factors in poultry slaughterhouse workers.

Design Descriptive, cross-sectional study.

Setting Three poultry slaughterhouses in the South of Brazil.

Participants This paper included 925 workers of 3 poultry slaughterhouses, 575 women and 350 men. The selection of the participants was random.

Main outcome measure Workers were asked about individual factors, work organiation, perception of bodily discomfort and cold, as well as ingestion of pain medication. Crude and adjusted ORs were estimated and $95 \%$ Cls were derived from binary logistic regression analysis for perception of bodily discomfort.

Results There was a significant association $(p<0.05)$ between perception of bodily discomfort and female gender ( $\mathrm{OR}=1.77 ; 95 \% \mathrm{Cl} 1.30$ to 2.41 ), performance of repetitive tasks $(\mathrm{OR}=1.81 ; 95 \% \mathrm{Cl} 1.12$ to 2.91$)$ and perception of cold $(\mathrm{OR}=2.05 ; 95 \% \mathrm{Cl} 1.44$ to 2.91$)$. Conclusions The findings of this research demonstrated that the sector of occupational safety and health management in poultry slaughterhouses should monitor the symptoms of WMSD among their workers, especially female workers, workers who perform repetitive tasks, as well as those who perform tasks in cold environments because these groups are more likely to experience bodily discomfort.

\section{INTRODUCTION}

According to the Annual Report of the Brazilian Association of Animal Protein, Brazil is the leader in poultry meat exports and the second largest producer in the world
Strengths and limitations of this study

- A larger sample was analysed using a more robust statistical treatment than previous studies on bodily discomfort in poultry slaughterhouses.

- This paper provided results that will be useful in assisting occupational health and safety professionals of poultry slaughterhouses in prevention programmes on work-related musculoskeletal disorders and supporting the actions of the Ministry of Labour.

- This study only considered if workers took rest breaks, but not the rest distribution throughout the workday, in addition to whether job rotations were performed, but not the task requirements, which were study limitations.

(13.06 millions of tons, in 2017). ${ }^{1}$ Production has grown in Brazilian poultry slaughterhouses, ${ }^{1} 2$ and approximately 350000 employees work directly in these slaughterhouses. ${ }^{3}$ In one slaughterhouse with 1280 workers, 150000 chickens were slaughtered per day $^{4}$; in another one with 3000 workers, 300000 chickens were slaughtered per day ${ }^{5}$; and in the third one with 1200 workers, 100000 chickens were slaughtered per day. ${ }^{6}$

As reported by the Occupational Safety and Health Administration (OSHA), ${ }^{7}$ several ergonomics-related risk factors may lead to the development of work-related musculoskeletal disorders (WMSDs) among poultry slaughterhouse workers: repetition, forceful exertion, awkward and static postures, vibration, and cold temperatures. In addition, another factor was mentioned as risk in slaughterhouses: use of manual tools and gloves. ${ }^{8}$ The industry of slaughtering and processing meat and derivatives is in the 11th 
place among the different economic activities that most develop occupational diseases in Brazil. ${ }^{10}$

Some studies used the OCRA Checklist method (Occupational Repetitive Actions) and found that most of the tasks in slaughterhouses represented high risk $(56 \%)^{4}$ and moderate risk (77\% and $63 \%$, respectively). ${ }^{56}$ Thus, it was concluded that these workers were vulnerable to ergonomic hazards through repetitive movements and a greater probability of developing upper-limb WMSDs (UL-WMSDs). ${ }^{4-6}$

In the workplace, workers frequently report some episodes of pain or discomfort associated with work activities. ${ }^{11}$ Discomfort is seen as an unpleasant state of the human body in reaction to its physical environment, ${ }^{12}$ and feelings of pain, soreness, numbness, fatigue, auditory and thermal discomfort, as well as anxiety. ${ }^{13}$ Conforming to Werner et $a l^{11}$ although discomfort ratings are not a specific diagnosis, it is a valuable marker for UL-WMSDs because most musculoskeletal disorders present pain or discomfort as the initial complaint. Such disorders involve significant pain, and in many cases their diagnoses are based on the nature and extent of the pain reported by the person. ${ }^{14}$ Programmes to prevent WMSDs should look for signs of a potential WMSD in the workplace, such as frequent worker reports of aches and pains or tasks requiring repetitive and forceful exertions, and take measures to reduce them. ${ }^{15}$

Poultry slaughterhouse workers feel bodily discomfort in the shoulders $(45.0 \%)$, neck $(29.0 \%)$, spine $(26 \%)$, arms $(23 \%)$, hands $(20 \%)$ and wrists $(20 \%) .{ }^{16}$ After investigating 595 slaughterhouse workers in Denmark, the prevalence of pain in the neck, shoulder, elbow and hand/wrist was $48 \%, 60 \%, 40 \%$ and $52 \%$, respectively. ${ }^{17}$ Although previous studies have already evaluated bodily discomfort in workers of poultry slaughterhouses, they only presented descriptive analyses (percentage) ${ }^{17}$ and limited samplings (case study). ${ }^{16}$

Studies on the association of bodily discomfort and risk factor exposures among poultry slaughterhouse workers are needed in order to provide information that guides health and safety professionals and the Ministry of Labour in adopting preventive measures to promote the health of these workers. Therefore, the aim of this study was to evaluate the association between perception of bodily discomfort and individual and work organisational factors among poultry slaughterhouse workers.

\section{METHODS}

\section{Study design and setting}

The research was conducted in three poultry slaughterhouses in the South of Brazil, with an average of 4000 workers (table 1). The participants worked in natural (scalding) and artificially cold environment $\left(8^{\circ} \mathrm{C}-12^{\circ} \mathrm{C}\right)$ (cutting and shipping), and used personal protective equipment (PPE) (clothing, aprons, gloves, socks and boots) provided by the slaughterhouses, with a Certificate of Approval from the Brazilian Ministry of Labour.

\section{Selection of participants}

The selection method of the slaughterhouses was intentional (South of Brazil), but the workers were selected randomly. The company provided a list of all workers' names, selecting the fifth name on the list followed by the tenth and so on. The workers were invited to participate in the research; if consent was given (eligibility criteria), he/she was taken to a private room to be interviewed. All invited participants agreed to be part of this study.

\section{Measures}

Workers were asked about individual factors (age and length of time working at the company), work organisation (presence of job rotation, rest breaks and tool use), perception of bodily discomfort and cold, and ingestion of pain medication. In this paper, the workers who used tools used a knife and a knife-sharpener. Tool use is considered a risk factor for the development of $\mathrm{WMSD}^{7}$; thus, it was included in statistical analyses. When the worker

\begin{tabular}{|c|c|c|c|c|}
\hline & Slaughterhouse 1 & Slaughterhouse 2 & Slaughterhouse 3 & Total \\
\hline Total workers (n) & 3000 & 3500 & 5000 & 11500 \\
\hline Participants (n) & 241 & 312 & 372 & 925 \\
\hline Physical exercise (PE) & Yes & Yes & No & \\
\hline Daily working time (hours, min) & 7 hours $20 \mathrm{~min}$ & 8 hours $48 \mathrm{~min}$ & 8 hours $48 \mathrm{~min}$ & \\
\hline Repetitive work (min/workday) & $407 \mathrm{~min}$ & $489 \mathrm{~min}$ & $481 \mathrm{~min}$ & \\
\hline Uniform change (min/workday) & $15 \mathrm{~min}$ & $15 \mathrm{~min}$ & $15 \mathrm{~min}$ & \\
\hline Work shifts (n) & 3 & 2 & 2 & \\
\hline Rest breaks (n) & 3 & 5 & 5 & \\
\hline Prescribed rest breaks & $\begin{array}{l}10 \text { min break } \\
8 \text { min }-P E \\
60 \text { min meal }\end{array}$ & $\begin{array}{l}2 \times 8 \text { min breaks } \\
5-8 \text { min }-P E \\
15 \text { min coffee } \\
45 \text { min meal }\end{array}$ & $\begin{array}{l}4 \times 8 \text { min breaks } \\
60 \text { min meal }\end{array}$ & \\
\hline
\end{tabular}


uses a knife and knife-sharpener, he/she performs more technical actions and uses upper-limb strength to accomplish the tasks, which can cause bodily discomfort. Annotations about the work environment where the worker performed his/her tasks (natural or artificially cold environment) and gender were recorded.

The worker was asked about bodily discomfort, that is, if he/she presented any of the symptoms: pain, fatigue, shocks, cracks, numbness, tingling, weight, strength loss and movement limitation in any part of the body. ${ }^{18}$ In order to evaluate the intensity level of discomfort perceived, a 3-point scale was used (mild, moderate and severe). If the worker answered more than one body region, the region with the highest degree of discomfort was considered to perform the statistical test.

With regard to the thermal sensation of workers in the workplace, it was asked if they felt cold in general. Thermal comfort is defined by the American Society of Heating, Refrigerating and Air-Conditioning Engineers- $55^{19}$ as the condition of mind that expresses satisfaction with the thermal environment, and is assessed subjectively.

To analyse task characteristics (repetitiveness), the criterion of the OCRA Checklist method was used. ${ }^{20}$ This method examines upper-limb risk factors: work organisation (to determine the duration of multiplier factor), lack of recovery periods, repetitiveness (frequency of technical actions), force demand, inappropriate postures and movements, stereotypy, and other additional factors. ${ }^{20}$ OCRA was chosen by the authors to evaluate repeatability, since it is specific for this purpose and is the preferred method by ISO (International Organization for Standardization) $11228-3^{21}$ to assess the manual handling of low loads at high frequency and provides criteria based on extensive epidemiological data to forecast the occurrence of UL-WMSD in exposed working populations.

According to Colombini and Occhipinti, ${ }^{22}$ repetitive tasks are characterised as cycles (regardless of the duration) with upper-limb movements or repetition of the same work gesture for the majority of the time (over half of the total time). To evaluate the frequency of technical actions of the workers, a Sony HDR-XR160 digital camcorder was used. Workers were videotaped for at least 5 min while performing their tasks or 10 task cycles.

Data were collected from the workers of all work shifts (table 1) prior to the implementation of the Brazilian Regulatory Norm 36 (NR-36) ${ }^{23}$ in 2013. This norm establishes the minimum requirements for evaluation, control and monitoring risks in tasks performed in the meat processing industry. The NR-36 determines the obligations of working conditions, such as the implementation of psychophysiological breaks, job rotation, furniture and workstation suitability, tool use, risk management, adequate work pace, and others. ${ }^{23}$ It is important to emphasise this because in future studies these variables may interfere with the outcome of studies on bodily discomfort among poultry slaughterhouse workers.

\section{Statistical analysis}

The effect size was calculated based on a significance level of 5\% (type I error), and a test power of $80 \%$ (type II error) was adopted for statistical analysis through binary logistic regression. Considering the sample size of 925 workers, it was possible to detect the effect size for OR of 1.260 when comparing the two groups. ${ }^{24}$

Binary logistic regression models were used to assess the association between perception of bodily discomfort and the independent variables: age, gender, length of time working at the company, work shifts, task characteristics, rest breaks, job rotation, tool use, perception of cold and ambient temperature (table 2).

Considering that slaughterhouses 2 and 3 had only two work shifts, only the morning and afternoon shifts of the three slaughterhouses were included in the present study in order to reduce assessment bias and allow a more consistent comparison among these groups (table 1).

OR and $95 \%$ CIs for perception of bodily discomfort were estimated for crude and adjusted analyses. First, the crude model was performed between perception of bodily discomfort and the independent variables separately. In order for the variables to be included in the adjusted model, they should present $\mathrm{p}<0.20$ in the crude model. Based on the results of the crude analysis, the adjusted model included the following independent variables to decrease the effect of confounding: gender, length of time working at the company, task characteristics, frequency of rest breaks, perception of cold and ambient temperature.

Multinomial logistic regression model was used to evaluate the association between the intensity of bodily discomfort and the ingestion of medicine. Appraisals were performed using the SPSS V.21.0 software and a value of $p \leq 0.05$ was considered significant.

\section{Patient and public involvement}

Patients and the public were not involved in the design of the study.

\section{RESULTS}

The research included 925 workers from 3 poultry slaughterhouses, 575 women and 350 men with a mean age of 33.4 years (range 18-52 years) and 34.6 years (range 18-54 years), respectively. The workers had been employed in the company for at least 1 month and at a maximum of 35 years (average $8.4 \pm 7.1$ years).

Table 1 shows the description of the total number of workers, the number of study participants, whether the company offered physical exercise to workers, the daily workload, the effective repetitive working hours, the number and detailed description of rest breaks prescribed, and the number of work shifts in each slaughterhouse surveyed.

When analysing each slaughterhouse separately, the following was observed: were mostly female workers, performed repetitive tasks, took rest breaks, worked in an 
Table 2 Frequency distribution of the individual and work organisational factors in slaughterhouses

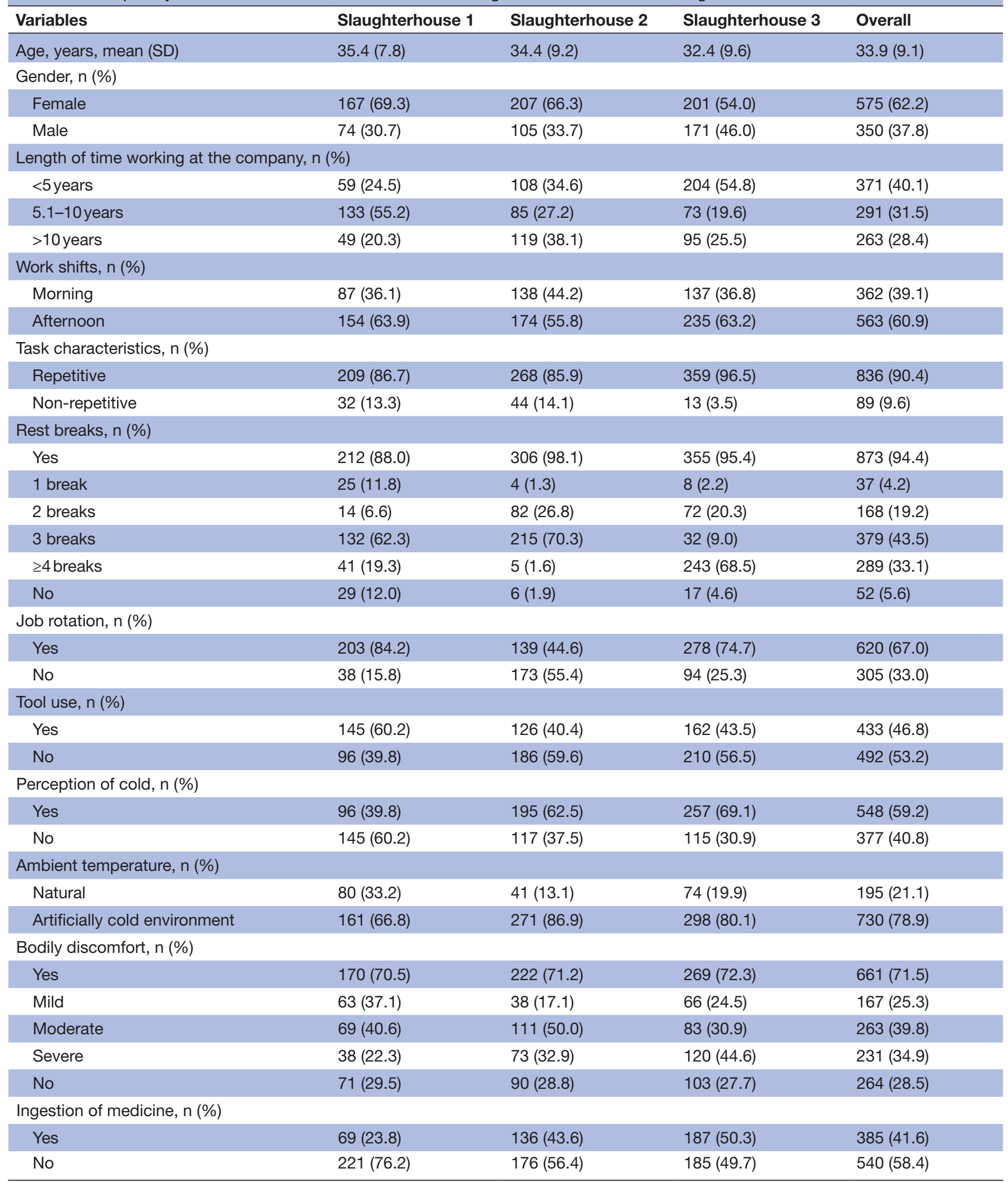

artificially cold environment and felt bodily discomfort (table 2).

Of the 661 workers who reported bodily discomfort, $58.2 \%$ ingested medicine to attenuate the symptoms reported. The result of the multinomial logistic regression showed that ingestion of pain medication was significantly associated with the intensity of the discomfort, being moderate ( $\mathrm{OR}=2.11 ; 95 \% \mathrm{CI} 1.42$ to 2.76$)$ and severe $(\mathrm{OR}=3.65 ; 95 \% \mathrm{CI} 2.40$ to 5.56$)$ compared with mild discomfort. 
Table 3 Frequency and percentage of the variables in relation to bodily discomfort and crude and adjusted associations between bodily discomfort and individual and work organisational factors

\begin{tabular}{|c|c|c|c|c|c|c|c|}
\hline & \multicolumn{3}{|c|}{ Bodily discomfort } & \multicolumn{2}{|l|}{ Crude } & \multicolumn{2}{|l|}{ Adjusted } \\
\hline & Yes, n (\%) & No, n (\%) & Total & OR (95\% Cl) & $p$ value & OR (95\% Cl) & $p$ value \\
\hline Age & & & & 1.01 (0.99 to 1.02$)$ & 0.426 & - & - \\
\hline Gender & & & & & $<0.001^{*}$ & & $<0.001^{\star *}$ \\
\hline Female & $443(77.0)$ & $132(23.0)$ & 575 & 2.03 (1.52 to 2.72$)$ & & $1.77(1.30$ to 2.41$)$ & \\
\hline Male & $218(62.3)$ & $132(37.7)$ & 350 & 1 & & 1 & \\
\hline Length of time working at the $c$ & company & & & & $0.169^{*}$ & & 0.073 \\
\hline$<5$ years & $258(69.5)$ & $113(30.5)$ & 371 & $1.00(0.71$ to 1.41$)$ & & 0.76 (0.53 to 1.10$)$ & \\
\hline $5.1-10$ years & $220(75.6)$ & $71(24.4)$ & 291 & $1.36(0.93$ to 1.97$)$ & & $1.16(0.78$ to 1.72$)$ & \\
\hline$>10$ years & $183(69.6)$ & $80(30.4)$ & 263 & 1 & & 1 & \\
\hline Work shifts & & & & & 0.397 & & - \\
\hline Morning & 253 (69.9) & $109(30.1)$ & 362 & 0.88 (0.66 to 1.18$)$ & & - & \\
\hline Afternoon & 408 (72.5) & $155(27.5)$ & 563 & 1 & & - & \\
\hline Task characteristics & & & & & $<0.001^{*}$ & & $0.015^{\star \star}$ \\
\hline Repetitive & $612(73.2)$ & $224(26.8)$ & 836 & 2.23 (1.43 to 3.48$)$ & & $1.81(1.12$ to 2.91$)$ & \\
\hline Non-repetitive & $49(55.1)$ & $40(44.9)$ & 89 & 1 & & 1 & \\
\hline Rest breaks & & & & & 0.228 & & - \\
\hline Yes & $620(71.0)$ & $253(29.0)$ & 873 & 0.66 (0.33 to 1.3$)$ & & - & \\
\hline No & $41(78.8)$ & $11(21.2)$ & 52 & 1 & & - & \\
\hline Frequency of rest breaks & & & & & $0.200^{*}$ & & 0.072 \\
\hline 0 break & $41(78.8)$ & $11(21.2)$ & 52 & 1 & & 1 & \\
\hline 1 break & $21(56.8)$ & $16(43.2)$ & 37 & $0.35(0.14$ to 0.89$)$ & & 0.26 (0.10 to 0.68$)$ & \\
\hline 2 breaks & $125(74.4)$ & $43(25.6)$ & 168 & $0.78(0.37$ to 1.65$)$ & & $0.61(0.28$ to 1.33$)$ & \\
\hline 3 breaks & $270(71.2)$ & $109(28.8)$ & 379 & 0.67 (0.33 to 1.34$)$ & & 0.48 (0.23 to 1.02$)$ & \\
\hline$\geq 4$ breaks & 204 (70.6) & 85 (29.4) & 289 & $0.64(0.32$ to 1.31$)$ & & $0.51(0.24$ to 1.08$)$ & \\
\hline Job rotation & & & & & 0.883 & & - \\
\hline Yes & $444(71.6)$ & $176(28.4)$ & 620 & 1.02 (0.76 to 1.39$)$ & & - & \\
\hline No & $217(71.1)$ & $88(28.9)$ & 305 & 1 & & - & \\
\hline Tool use & & & & & 0.504 & & - \\
\hline Yes & 314 (72.5) & 119 (27.5) & 433 & $1.10(0.83$ to 1.47$)$ & & - & \\
\hline No & 347 (70.5) & $145(29.5)$ & 492 & 1 & & - & \\
\hline Perception of cold & & & & & $<0.001^{*}$ & & $<0.001^{\star \star}$ \\
\hline Yes & $426(77.7)$ & $122(22.3)$ & 548 & 2.11 (1.58 to 2.82$)$ & & 2.05 (1.44 to 2.91$)$ & \\
\hline No & $235(62.3)$ & $142(37.7)$ & 377 & 1 & & 1 & \\
\hline Ambient temperature & & & & & $0.065^{*}$ & & 0.415 \\
\hline Natural & $129(66.2)$ & $66(33.8)$ & 195 & $0.73(0.52$ to 1.02$)$ & & $1.20(0.78$ to 1.85$)$ & \\
\hline Artificially cold environment & $532(72.9)$ & $198(27.1)$ & 730 & 1 & & & \\
\hline
\end{tabular}

Adjusted for gender, work shifts, task characteristics, perception of cold and ambient temperature. ${ }^{*} \mathrm{p}<0.20,{ }^{* *} \mathrm{p} \leq 0.05$.

Table 3 shows the frequency and percentage of the variables and the associations between perception of bodily discomfort and individual and work organisational factors in the crude model and the adjusted model for gender, length of time working at the company, task characteristics, frequency of rest breaks, perception of cold and ambient temperature.
The risk of a poultry slaughterhouse female worker feeling bodily discomfort is $77 \%$ higher than a male worker. The risk of a slaughterhouse worker feeling bodily discomfort is $81 \%$ higher for those who perform repetitive tasks compared with those who do not perform repetitive tasks, and 105\% higher for those who feel cold compared with those who do not. Finally, bodily 
discomfort did not have any association with the length of time working at the company, frequency of rest breaks and ambient temperatures of the workplace $(p>0.05)$.

\section{DISCUSSION}

This paper indicates that most of the workers in each of the three surveyed poultry slaughterhouses felt bodily discomfort, and other studies corroborate these findings. ${ }^{16} 1725$ There are possible explanations for this outcome, mainly that poultry slaughterhouse workers are exposed to several occupational risk factors. ${ }^{7}$ Production has grown in Brazilian poultry slaughterhouses, ${ }^{12}$ a fact which subjected the workers to risks, since studies evidenced that majority of slaughterhouse workers were exposed to ergonomic hazards by repetitive movements and a greater probability of developing UL-WMSDs ( $>21.5 \%$ probability for high risk and $10.8 \%-21.5 \%$ for moderate risk) ${ }^{4-6}$ Data collection was performed before the implementation of NR-36, ${ }^{23}$ where workday duration, total time, frequency and distribution of rest breaks per day, overtime performance, and job rotation were not rigidly determined and controlled. Consequently, the physical demand of workers was higher before this norm, and these organisational issues could aggravate bodily discomfort in workers. As a result of these conditions, the industry of slaughtering and processing meat and derivatives is in the 11th place among the different economic activities that most develop occupational diseases in Brazil. ${ }^{10}$ It was verified that the greater the intensity of bodily discomfort, the greater the possibility of taking pain medication. In this research, majority of workers were taking pain medication $(57.1 \%)$, unlike the study conducted on 195 workers in which bodily discomfort was reported and $24.6 \%$ were taking medication to attenuate the symptoms. ${ }^{25}$ The use of stimulant medication (methamphetamine) improved an action or skill, while increasing productivity and the ability to function normally, ${ }^{26}$ and may help to transform unrealistic industry demands to attainable goals for workers on the production line. ${ }^{27}$ The ingestion of pain medication could be a strategy for the worker to continue working; however, it is not the healthiest and safest way to meet the production demand required by slaughterhouses.

In the present research, the OR of women feeling bodily discomfort is higher than men. This is confirmed by several studies. ${ }^{28-30}$ Assunção and $\mathrm{Abreu}^{28}$ analysed 60 202 Brazilians and found that one of the factors associated with a greater possibility of occurrence of WMSD was female gender ( $\mathrm{OR}=2.33 ; 95 \%$ CI 1.72 to 3.15$)$. One research with 12410 adults aged 20-59 years from 47 occupational groups in 18 countries showed that widespread pain was associated with an increased prevalence among female workers ( $\mathrm{OR}=0.9 ; 95 \%$ CI 0.8 to 1.0$)$, and the association with the number of anatomical sites was significantly higher for women with $6-10$ pain sites $(\mathrm{OR}=1.6 ; 95 \% \mathrm{CI} 1.2$ to 2.1$)$ in relation to men. ${ }^{29}$ In nine poultry slaughterhouses in Quebec $(n=661)$, WMSDs are more common among women than men. This appears to be because women are more exposed to risk factors associated with extended periods of standing, more repetitive movements and a very rapid work pace. ${ }^{30}$

One ergonomics-related risk factor that may lead to the development of WMSDs in poultry processing facilities is repetition, performing the same motion or series of motions continually or frequently. ${ }^{7}$ Studies on poultry slaughterhouses observed that most of the tasks were considered of moderate risk $\left(63 \%{ }^{6}\right.$ and $\left.77 \%{ }^{5}\right)$, although it was classified as high risk $(56 \%)$ in another study. ${ }^{4}$ The results both of this and other studies ${ }^{4-6}$ concluded that most of the slaughterhouse workers were vulnerable to ergonomic hazards by repetitive movements, with an average of 55-64 technical actions per minute. ${ }^{4-6}$ These studies show that work pace was high in poultry slaughterhouses, tasks were repetitive, and most tasks presented high and moderate risks, corroborating the hypothesis that poultry slaughterhouse workers' bodily discomfort is associated with repetitiveness, which is a risk factor for developing WMSDs.

The result of this study confirmed what was cited by OSHA ${ }^{7}$ that cold temperatures are also a risk factor for the development of WMSDs among poultry slaughterhouse workers. Another analysis established that feeling cold is associated with bodily discomfort $(p=0.035){ }^{25}$ Slaughterhouse workers are subjected to many conditions that can aggravate the sensation of cold and require preventative measures. According to NR-36, when manual tasks are performed in cold environments or require constant contact with cold surfaces and cold products, workers should have a hand warming system available near toilets or break rooms. ${ }^{23}$ Although there were recommendations in relation to finger temperatures $\left(>24^{\circ} \mathrm{C}\right.$ during prolonged exposure, or down to $15^{\circ} \mathrm{C}$ when sporadic), ${ }^{31}$ studies discovered that $78 \%$ of poultry slaughterhouse workers ${ }^{32}$ and $66 \%$ of pig slaughterhouse workers reported feeling cold in their hands. ${ }^{33}$ Güths et $a l^{34}$ mentioned that the finger temperature reached $16^{\circ} \mathrm{C}$ in a poultry slaughterhouse worker. Prolonged exposure to cold, often associated with insufficient clothing or physical activity, may result in whole-body cooling and a decrease in core temperature. ${ }^{35}$ According to Tirloni et $a l,{ }^{33}$ working in cold environments, handling cold products and using handheld tools and gloves should be monitored and measures taken to prevent WMSDs.

Future studies should associate bodily discomfort and the variables of job rotations, rest breaks, and tool and glove use, however in more detail. The results indicate that workers' safety and health team and the Ministry of Labour should prioritise risk reduction in slaughterhouses in relation to women, repetitiveness and cold environments-repetitiveness by reducing work pace, hiring of workers to meet production demand, shortening the length of working day and no overtime. With regard to cold, the reduction of this risk could be achieved through acquisition of PPE with adequate thermal insulation, but it should also be suitable to workers' anthropometry and 
task performance. Additionally, PPE should be replaced when it becomes inefficient for insulation.

\section{Strengths and limitations}

One study limitation was that the three slaughterhouses did not have three work shifts. So it was decided to exclude workers from the night shift of slaughterhouse 1 because this might have resulted in bias due to lack of night shifts in slaughterhouses 2 and 3. It allowed a more consistent comparison between work shifts in each slaughterhouse and validity of the conclusion of this study. Another limitation is that the investigation only considered if workers took rest breaks, but not the rest distribution throughout the workday nor its duration, in addition to whether job rotations were performed, but not the task requirements (eg, if the job rotation fulfilled at least one condition of the NR-36). Future studies should measure these variables in detail and analyse their association with bodily discomfort, besides controlling the external tasks of the workday performed by workers that could interfere with the results of the paper. In this study, sample selection bias occurred due to the non-probabilistic (intentionalSouth of Brazil) selection of slaughterhouses. Thus, the sample was not representative of the researched population; consequently, it precludes generalisation of the data to all slaughterhouse workers in Brazil. Conversely, this research was exploratory and the first to investigate the associations of bodily discomfort in a large sample of workers in Brazil.

\section{CONCLUSIONS}

In general, the majority of poultry slaughterhouse workers were female, felt bodily discomfort, worked in the afternoon shift, performed repetitive tasks and job rotations, took rest breaks, perceived cold, worked in an artificially cold environment, did not use a tool and did not ingest pain medication. Nevertheless, among workers who presented bodily discomfort, it was found that the greater the intensity of the discomfort, the greater the possibility of taking pain medication. There was an association between perception of bodily discomfort and gender, task characteristics and perception of cold. Female workers, workers who perform repetitive tasks and those who feel cold are more likely to experience bodily discomfort.

It is suggested that the occupational safety and health management sector in poultry slaughterhouses should monitor the symptoms of WMSDs among their workers, such as bodily discomfort. This control can prevent ingestion of pain medication among workers and correct the ergonomic inadequacies that trigger bodily discomfort. Especially women should be well informed about the risk factors of developing WMSDs and how to prevent these exposures.

Contributors AST, DCdR, AFB and ARPM were involved in the conception and design of the research, data collection and revision of the manuscript. AST and AFB analysed the data and interpreted the results. AST and DCdR added and formatted the figures and tables, as well as drafted and approved the final version of the manuscript.

Funding The authors have not declared a specific grant for this research from any funding agency in the public, commercial or not-for-profit sectors.

Competing interests None declared.

Patient consent for publication Not required.

Ethics approval The study was approved by the Ethics Committee of the Federal University of Santa Catarina, Brazil (2098/11), in accordance with the Helsinki Declaration.

Provenance and peer review Not commissioned; externally peer reviewed.

Data sharing statement No additional data available.

Open access This is an open access article distributed in accordance with the Creative Commons Attribution Non Commercial (CC BY-NC 4.0) license, which permits others to distribute, remix, adapt, build upon this work non-commercially, and license their derivative works on different terms, provided the original work is properly cited, appropriate credit is given, any changes made indicated, and the use is non-commercial. See: http://creativecommons.org/licenses/by-nc/4.0/.

\section{REFERENCES}

1. Brazilian Association of Animal Protein. Annual Report. 2018 http:// abpa-br.com.br/storage/files/relatorio-anual-2018.pdf (Accessed 20 Aug 2018).

2. Sardá S, Ruiz RC, Kirtschig G. Juridical tutelage concerning the health of meat packing-workers: public service considerations. ActaFisiátr 2009;16:59-65.

3. Brazilian Association of Animal Protein. Resumo do Setor de Aves. http://abpa-br.com.br/setores/avicultura/resumo (Accessed 23 Aug 2018).

4. Reis DC, Reis PF, Moro ARP, et al. Assessment of risk factors of musculoskeletal disorders in poultry slaughterhouse. In: Azeres P, Baptista JS, Barroso MP, eds. Proceedings book of the international symposium on occupational safety and hygiene - SHO2015. 1st edn. Guimarães, Portugal: Sociedade Portuguesa de Segurança e Higiene Ocupacionais, 2015:294-6.

5. Reis D, Moro A, Ramos E, et al. Upper Limbs Exposure to Biomechanical Overload: Occupational Risk Assessment in a Poultry Slaughterhouse. In: Goonetilleke R, Karwowski W, eds. Advances in Physical Ergonomics and Human Factors. . 1st edn. Orlando, FL: Springer International Publishing, 2016:489. 275-82.

6. Reis DCdos, Tirloni AS, Ramos E, et al. G3-2 Assessment of risk factors of upper-limb musculoskeletal disorders in a chicken slaughterhouse. Jpn J Ergon 2017;53(Supplement2):S458-61.

7. Occupational Safety and Health Administration (OSHA). Prevention of musculoskeletal injuries in poultry processing. $2013 \mathrm{https}: / / \mathrm{www}$. osha.gov/Publications/OSHA3213.pdf (Accessed 30 Sep 2016).

8. Colombini D, Occhipinti E. Preventing upper limb work-related musculoskeletal disorders (UL-WMSDS): new approaches in job (re)design and current trends in standardization. Appl Ergon 2006;37:441-50.

9. Toulouse G, Slaughterhouses RJG. International encyclopedia of ergonomics and human factors. 2nd edn. Boca Raton, FL: Taylor \& Francis Group, 2006:2772-5.

10. Smartlab: Observatório Digital de Saúde e Segurança do Trabalho. Brasília-DF. 2012-2017. https://observatoriosst.mpt.mp.br/ (Accessed 09 Apr 2018).

11. Werner RA, Franzblau A, Gell N, et al. Predictors of upper extremity discomfort: a longitudinal study of industrial and clerical workers. $J$ Occup Rehabil 2005;15:27-35.

12. Vink P, Hallbeck S. Editorial: comfort and discomfort studies demonstrate the need for a new model. Appl Ergon 2012;43:271-6.

13. Zhang L, Helander MG, Drury CG. Identifying factors of comfort and discomfort in sitting. Hum Factors 1996;38:377-89.

14. Carayon P, Smith MJ, Haims MC. Work organization, job stress, and work-related musculoskeletal disorders. Hum Factors 1999;41:644-63.

15. Center for Disease Control and Prevention. Workplace Health Promotion. Work-Related Musculoskeletal Disorders (WMSDs) Evaluation Measures. 2016 https://www.cdc.gov/workplacehealthp romotion/health-strategies/musculoskeletal-disorders/evaluationmeasures/index.html (Accessed 11 Sep 2017).

16. Reis P, Moro A. Preventing Rsi/Wruld: use of esthesiometry to assess hand tactile sensitivity of slaughterhouse workers. Work 2012;41(Suppl 1):2556-62. 
17. Sundstrup E, Jakobsen MD, Jay K, et al. High intensity physical exercise and pain in the neck and upper limb among slaughterhouse workers: cross-sectional study. Biomed Res Int 2014;2014:1-5.

18. Couto HA. Ergonomia aplicada ao trabalho: conteúdo básico: guia prático. Belo Horizonte: ERGO, 2007.

19. American Society of Heating, Refrigerating and Air-conditioning Engineers, Inc. Thermal Environmental Conditions for Human Occupancy (ASHRAE Standard 55). Atlanta, GA: ASHRAE, 2010.

20. Colombini D, Occhipinti E. Método Ocra para análise e a prevenção do risco por movimentos repetitivos: manual para a avaliação e a gestão do risco. Curitiba, Brasil: Escola Ocra Brasiliana, 2014.

21. International Organization for Standardization (ISO). ISO 11228-3:2007:Ergonomics - manual handling - Part 3: handling of low loads at high frequency. Geneva: ISO, 2007.

22. Colombini $D$, Occhipinti E. Risultati della valutazione del rischio e del danno in gruppi di lavoratori esposti, in diversi comparti lavorativi, a movimenti e sforzi ripetuti degli arti superiori. Med Lav 2004:95:233-46.

23. Brasil. Ministério do Trabalho. Norma Regulamentadora NR36 - Segurança e saúde no trabalho em empresas de abate e processamento de carnes e derivados. Brasil: Portaria MTE n 555 de 18 de abril de, 2013.

24. Demidenko E. Sample size determination for logistic regression revisited. Stat Med 2007;26:3385-97.

25. Tirloni AS, dos Reis DC, dos Santos JB, et al. Body discomfort in poultry slaughterhouse workers. Work 2012;41(Suppl 1):2420-5.

26. Lende DH, Leonard T, Sterk CE, et al. Functional methamphetamine use: the insider's perspective. Addict Res Theory 2007;15:465-77.
27. Hendrix JA, Dollar CB. American slaughterhouses and the need for speed: an examination of the meatpacking-methamphetamine hypothesis. Organ Environ 2017:1-19.

28. Assunção AÁ, Abreu MNS. Factor associated with self-reported work-related musculoskeletal disorders in Brazilian adults. Rev Saude Publica 2017;51(suppl 1):10s.

29. Coggon D, Ntani G, Palmer KT, et al. Patterns of multisite pain and associations with risk factors. Pain 2013;154:1769-77.

30. Mergler D, Brabant C, Vézina N, et al. The weaker sex? Men in women's working conditions report similar health symptoms. $J$ Occup Med 1987;29:417-21.

31. International Standards Organization (ISO). Ergonomics of the thermal environment - Determination and interpretation of cold stress when using required clothing insulation (IREQ) and local cooling effects. ISO 11079. Geneva, Switzerland: International Standards Organization, 2007.

32. Ramos E, Reis DCdos, Tirloni AS, et al. Thermographic analysis of the hands of poultry slaughterhouse workers exposed to artificially cold environment. Procedia Manuf 2015;3:4252-9.

33. Tirloni AS, Reis DCD, Ramos E, et al. Thermographic evaluation of the hands of pig slaughterhouse workers exposed to cold temperatures. Int J Environ Res Public Health 2017;14:838.

34. Güths S, Santos VA, Takeda F, et al. Body Temperature Monitoring System for Slaughterhouse Workers. In: Ahram T, Karwowski W, eds. Advances in Human Factors, Software, and Systems Engineering. 1st edn. Los Angeles: Springer, Cham, 2017:589. 96-105.

35. Holmér I, Hassi J, Ikäheimo TM, et al. Cold stress: effects on performance and health. Patty's Toxicol 2012;97:1-26. 